Pesq. Vet. Bras. 31(6):471-476, junho 2011

\title{
Hydrocortisone decreases apoptosis in jejunum of horses subjected to experimental ischemia and reperfusion ${ }^{1}$
}

\author{
Geraldo Eleno S. Alves ${ }^{2 *}$, Heloisa M.F. Mendes², Tiago G.S. Alves², Rafael R. \\ Faleiros $^{2}$, Anilton C. Vasconcelos ${ }^{3}$, Renato L. Santos ${ }^{2}$ \\ and Jorge J.M. Rio Tinto 4
}

\begin{abstract}
Alves G.E.S., Mendes H.M.F., Alves T.G.S., Faleiros R.R., Vasconcelos A.C., Santos R.L. \& Rio Tinto J.J.M. 2011. Hydrocortisone decreases apoptosis in jejunum of horses subjected to experimental ischemia and reperfusion. Pesquisa Veterinária Brasileira 31(6):471-476. Departamento de Clínica e Cirurgia Veterinárias, Escola de Veterinária, Universidade Federal de Minas Gerais, Belo Horizonte, MG 31270901, Brazil. E-mail: geraldo@ vet.ufmg.br

In order to evaluate the effect of hydrocortisone on apoptosis in the jejunum of horses subjected to ischemia and reperfusion, ten horses were paired and grouped into two groups - treated $(n=5)$ and non treated $(n=5)$. Segments of the jejunum were used as controls $(C)$, or as venous ischemia (VIsc), which were subjected to $2 \mathrm{~h}$ of ischemia followed by 2 or $12 \mathrm{~h}$ of reperfusion. C samples were collected at time zero (prior to ischemia) and VIsc samples were collected at $2 \mathrm{~h}$ of ischemia and at 2 and $12 \mathrm{~h}$ of reperfusion. TUNEL positive apoptotic cells were counted in 10 microscopical fields in deep mucosa from each horse throughout the time course. After $12 \mathrm{~h}$ of reperfusion, the number of apoptotic cells in treated group were significantly lower than in untreated animals, indicating that hydrocortisone inhibits apoptosis. These results indicate that hydrocortisone has a beneficial effects favoring the maintenance of jejunal integrity in horses with ischemia and reperfusion injuries by preventing apoptotic cell death.
\end{abstract}

INDEX TERMS: Horse, ischemia, reperfusion, glucocorticoid, apoptosis.

RESUMO.- [Hidrocortisona diminui a apoptose no jejuno de equinos sujeitos a isquemia e reperfusão experimentais.] Com o objetivo de avaliar o efeito da hidrocortisona sobre a apoptose no jejuno de equinos submetidos à isquemia e reperfusão, dez cavalos foram agrupados em dois grupos: tratado $(n=5)$ e não-tratado $(n=5)$. Foi utilizado um segmento do jejuno como controle $(\mathrm{C})$ e outro foi submetido a isquemia venosa (VIsc) por $2 \mathrm{~h}$ seguida de 2 ou $12 \mathrm{~h}$ de reperfusão. Amostras de $\mathrm{C}$ foram coletadas no tempo zero (antes da isquemia) e amostras de VIsc foram coletadas após

\footnotetext{
${ }^{1}$ Received on November 26, 2010.

Accepted for publication on January 22, 2011

2 Departamento de Clínica e Cirurgia Veterinárias, Escola de Veterinária, Universidade Federal de Minas Gerais (UFMG), Av. Antônio Carlos 6627, Pampulha, Belo Horizonte, MG 31270-901, Brazil. Research Fellows of the National Research Council (CNPq). ${ }^{*}$ Corresponding author: geraldo@ vet.ufmg.br

3 Instituto de Ciências Biológicas, UFMG, Belo Horizonte, MG 31270-901.

${ }^{4}$ Departamento de Veterinária, PUC-Betim, Rua do Rosário 1600, Bairro Angola, Betim, MG 32604-115, Brazil.
}

$2 \mathrm{~h}$ de isquemia e a $2 \mathrm{e} 12 \mathrm{~h}$ de reperfusão. Células apoptóticas TUNEL positivas foram contadas em 10 campos microscópicos da mucosa na região das criptas de cada animal em cada tempo. Após $12 \mathrm{~h}$ de reperfusão, o número de células apoptóticas no grupo tratado foram significativamente menores do que no grupo não-tratado, indicando que a hidrocortisona inibe a apoptose. Esses resultados mostram que a hidrocortisona tem efeito benéfico favorecendo a manutenção da integridade do jejuno em cavalos com lesão de isquemia e reperfusão por prevenir a morte celular por apoptose.

TERMOS DE INDEXAÇÃO: Equinos, isquemia, reperfusão, glicocorticóides, apoptose.

\section{INTRODUCTION}

Ischemia and reperfusion injuries (I/R) play a very important role in the pathophysiology of gastroenteric changes including strangulative obstructions, acute arterial occlusion, and hemodynamic shock. Suppression of blood flow during ischemia causes tissue damage, but paradoxically reestablishment of the blood flow intensifies the ischemia-induced 
lesions resulting in I/R injuries (Faleiros et al. 2001, Cerqueira et al. 2005). We have previously demonstrated I/R injuries associated with experimental obstruction of equine small colon and jejunum.( Faleiros et al. 2001, Alves et al. 2003).

Pathogenesis of I/R injuries has been intensively investigated (Alves et al. 2003), but due to its complexity, it remains not completely understood (Cerqueira et al. 2005). However, several studies have addressed therapeutic approaches for these injuries (Alves et al. 2003, Pagliosa et al. 2008, Pagliosa et al. 2009), including the use of hydrocortisone, which has beneficial effects (Alves et al. 2003).

Glucocorticoids (GC) are widely used in medicine because of its powerful anti-inflammatory effect. Furthermore, due to its immunosuppressive effect, it can also be used as a complementary drug in chemotherapy of patients with leukemia (Evans-Storms et al. 2000, Messmer et al. 1999). The reason for its use as an immunosuppressive drug is related to its ability to induce apoptosis in defense cells such as the lymphocytes (Evans-Storms et al. 2000).

In dogs with cutaneous mastocytoma, GC are often associated with other chemotherapeutic agents after surgical treatment, resulting in reduction of neoplastic cells both in vitro and in vivo, which may be attributed to induction of apoptosis (Takahashi et al. 1997). Similarly, in vitro study of canine tendon cells and chondrocytes have also demonstrated that dexamethasone increases apoptosis in these cells, preventing cellular proliferation (Houssain et al. 2008). Conversely, in vitro studies demonstrated that GC inhibit apoptosis of hepatoma cells in rats (Evans-Storms et al. 2000). In addition, GC suppress apoptosis in osteoblasts (Chae et al. 2000), and block apoptosis in the bovine glomerular endothelial cells (Messmer et al. 1999). Also in cattle, specifically hydrocortisone suppress apoptosis in luteal cells in cell culture (Komiyama et al. 2008). Therefore, GC can induce or inhibit apoptosis, depending upon cell type and interrelation of complex molecular mechanisms (Amsterdam et al. 2002).

Apoptosis is a type of cellular death that can be induced by either physiological or pathological stimuli. It is involved in cellular renewal in adult tissues or during the embryonic development (Kerr et al. 1972). It functions antagonizing the effects of mitosis or tissue proliferation, thus regulating the final tissue volume (Moro et al. 2004). It also plays a role in pathological processes such as autoimmune diseases, carcinogenesis, and ischemia/reperfusion injury (Parolin \& Reason 2001).

Studies with laboratory animals have demonstrated the involvement of apoptosis in I/R injuries in the intestine (lkeda et al. 1998, Noda et al. 1998). Recently, studies carried out by our research group demonstrated the involvement of apoptosis in the ischemia and reperfusion injuries in small colon of horses (Mendes et al. 2009). Considering the beneficial effect of sodium succinate of hydrocortisone (SSH) for treatment I/R injuries in horses (Alves et al. 2003, Faleiros et al. 2006), the goal of this study was to evaluate the effect of the SSH on apoptosis in jejunum of horses subjected to experimental ischemia and reperfusion.

\section{MATERIALS AND METHODS}

Animals and experimental design. Samples from a previously published study (Alves et al. 2003) were used in this study, which has been approved by the Institutional Committee for Ethics in Animal Experimentation (CETEA-UFMG, Protocol no189/08). Ten crossbreed horses were used. The horses were clinically evaluated, treated with moxidectin $(0.4 \mathrm{mg} / \mathrm{kg}, \mathrm{PO})$, and kept in collective poles receiving coast cross hay and mineral mix ad libitum, and commercial food with $12 \%$ of crude protein supplied to the approximate amount of $1 \%$ of body weight during at least seven days prior to the experiment. These horses were paired according to age, body condition, and weight, and then divided into two groups, namely treated (T) and non treated (NT).

The horses were fasted for $18 \mathrm{~h}$, pre-medicated with midazolan $(0.15 \mathrm{mg} / \mathrm{kg}, \mathrm{IV})$ and $10 \%$ guaiacol glyceryl ether until they became recumbent, followed by orotracheal intubation for induction and maintenance of the anesthesia with volatilized halothane through a thermo-compensated vaporizer. Surgeries of $\mathrm{T}$ and NT horses were alternated, and performed by the same surgical team. Each horse was subjected to the same model of $\mathrm{I} / \mathrm{R}$, through a pre-umbilical midline celiotomy of approximately $20 \mathrm{~cm}$. Two segments of the jejunum were demarcated from two meters of the oral extremity of the ileum-cecal fold, with an approximate length of $30 \mathrm{~cm}$, separated from each other by at least $15 \mathrm{~cm}$. These segments were isolated by placing clamps made with number 2 Penrose tubing to interrupt the mural circulation. In one segment, the mesenteric veins were dissected, and tied with number 1 Penrose tubing, producing total venous ischemia (segment VIsc). In the control segment (C) there was no interruption of mesenteric blood flow, but there was only interruption of the mural circulation. The phase of ischemia lasted for $2 \mathrm{~h}$, and it was followed by reestablishment of the blood flow and reperfusion for $12 \mathrm{~h}$. Laparorrhaphy and interruption of anesthesia was done at $2 \mathrm{~h}$ after the beginning of reperfusion. Blood flow was evaluated in the experimental intestinal segments at the beginning of the ischemia and of the reperfusion by using a Doppler ultrasound device, to verify absence and reestablishment of blood flow during ischemia and reperfusion, respectively.

One hour after the onset of ischemia, the $\mathrm{T}$ group received $4.0 \mathrm{mg} / \mathrm{kg}$ (IV), of hydrocortisone sodium succinate diluted in $500 \mathrm{ml}$ of $\mathrm{NaCl}$ isotonic solution administered during 10 minutes. The horses of the NT group were subjected to the same procedure, but received only $500 \mathrm{ml}$ of $\mathrm{NaCl}$ isotonic solution (placebo). At the end of the surgical procedure, the horses were allowed to recover from anesthesia receiving $0.1 \mathrm{mg} / \mathrm{kg}$ (IV) of butorphanol, and were then placed into individual stalls. During the postoperative period the horses received only water, and they were euthanatized at $12 \mathrm{~h}$ after the beginning of the reperfusion.

Samples from the $C$ segment were collected prior to instrumentation, and samples from the VIsc segment were collected at $2 \mathrm{~h}$ of ischemia, and at 2 and $12 \mathrm{~h}$ of reperfusion. These samples processed for paraffin embedding.

TUNEL staining. TUNEL was performed using a commercial kit (TdT-FragELTM DNA Fragmentation Detection; Calbiochem, USA) according to the manufacturer's instructions. Briefly, 5 $\mu \mathrm{m}$-thick sections mounted onto silanized slides were deparaffinized, washed in TBS (tris-buffered saline), treated with Triton $\mathrm{X}-100(0.5 \%)$ for 10 minutes followed by proteinase $\mathrm{K}(20 \mu \mathrm{g} / \mathrm{mL})$ at room temperature for 10 minutes. After washing in TBS, endogenous peroxidase was inactivated in a $3 \%$ 
hydrogen peroxide solution, rinsed in TBS, and incubated with an equilibration buffer. The sections were then incubated with TdT enzyme (terminal deoxynucleotidyl transferase) at $37^{\circ} \mathrm{C}$ for $1.5 \mathrm{~h}$ in a humidified chamber. The reaction was interrupted, and the sections were incubated with a conjugated antibody in a humidified chamber for 30 minutes. After washing in PBS, the reaction was detected using DAB (diaminobenzidine) for 4 minutes at room temperature. The sections were counterstained with methyl green. Samples were labeled as: control segment (C), and venous ischemia segments (VIsc) at $2 \mathrm{~h}$ ischemia (I2), at $2 \mathrm{~h}$ reperfusion (R2) and at $12 \mathrm{~h}$ reperfusion (R12).

Morphometric analysis. Digital images from 10 microscopic fields randomly selected at the base of the intestinal crypts from each TUNEL stained section were captured using a microcamera (Color Video Camera, JVC, Thailand) connected to an light microscope. The number of apoptotic epithelial cells

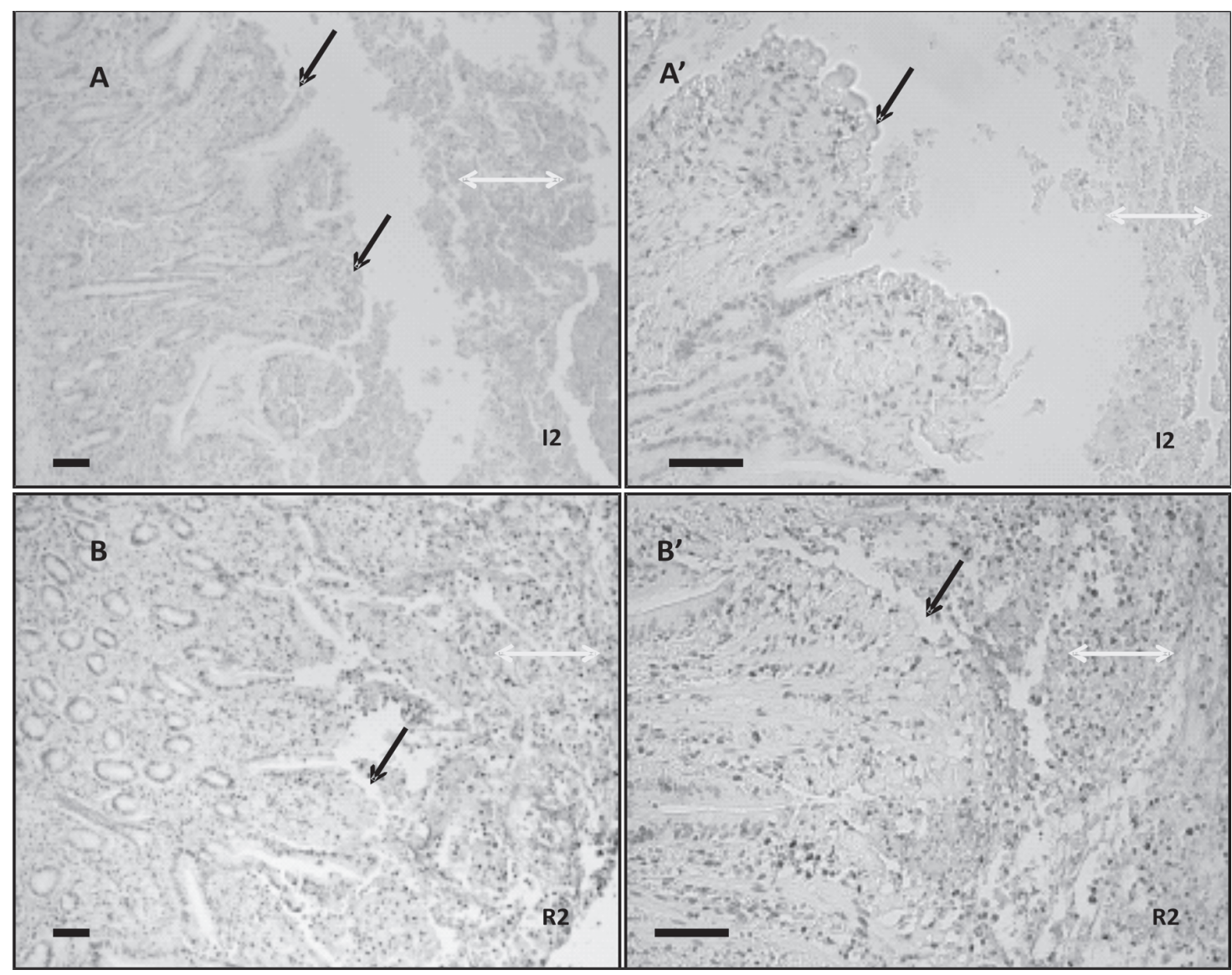

Fig.1. TUNEL stai-ned jejunum of horses subjected to experimental ischemia by 2 hours (I2) followed by 2 hours of reperfusion (R2). Black arrows indicates epithelial denudation of villi and laminae propria exposure. Yellow arrows indicates detached cells. Bar: $200 \mathrm{~mm}$.

was established based on positive TUNEL staining and at least one morphologic feature of apoptosis, including cell shrinkage, chromatin margination, nuclear condensation, and anoikis. A software was used for image analysis (Image Tool, v.3.0). Digital images were blindly examined by two researchers.

Statistical analyses. Data was statistically analyzed by performing repeated measures two-way Analysis of Variance (ANOVA) followed by the Student Newman Keuls test. Data was analyzed using the software Sigma Stat 3.5 (Systat Software Inc., USA) considering $P<0.05$.

\section{RESULTS}

A few apoptotic cells were detected all over the crypt-villus axis, but mainly in the region of the villus in the control group. After $2 \mathrm{~h}$ of ischemia (I2) and $2 \mathrm{~h}$ of reperfusion (R2), there was a marked change in the architecture in the villus. An intense positive TUNEL labeling indicated a higher level of apoptosis in this region of the mucosa during I/R. At this time point, the tips of the villi were completely disorganized, and the villi had reduced length with increased width. Epithelial

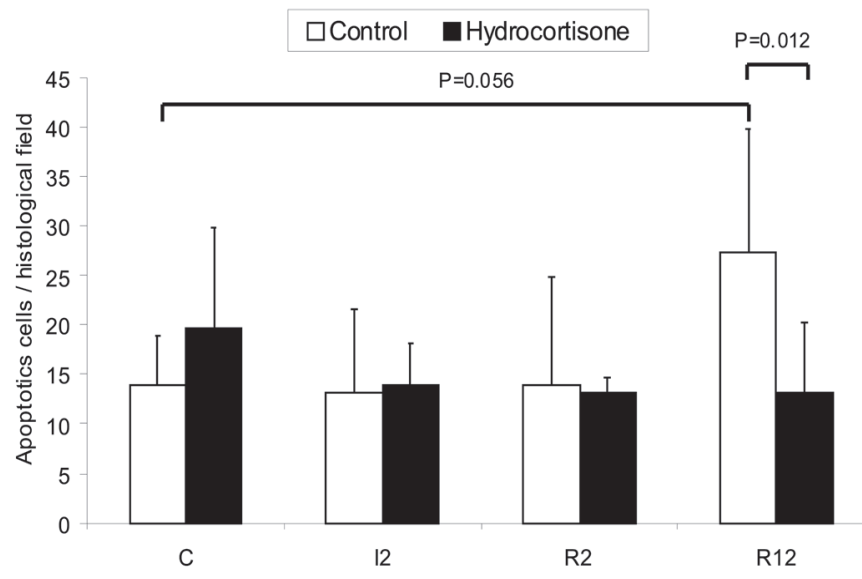

Fig.2. Mean ( \pm SD) apoptotic cells per histological field in the crypt region (deep mucosa) in the jejunum of horses subjected to ischemia and reperfusion. C (Control), I2 (2 h of ischemia), $\mathrm{R} 2$ ( $2 \mathrm{~h}$ of ischemia followed by $2 \mathrm{~h}$ of reperfusion), R12 ( $\mathrm{h}$ of ischemia followed by $12 \mathrm{~h}$ of reperfusion). 


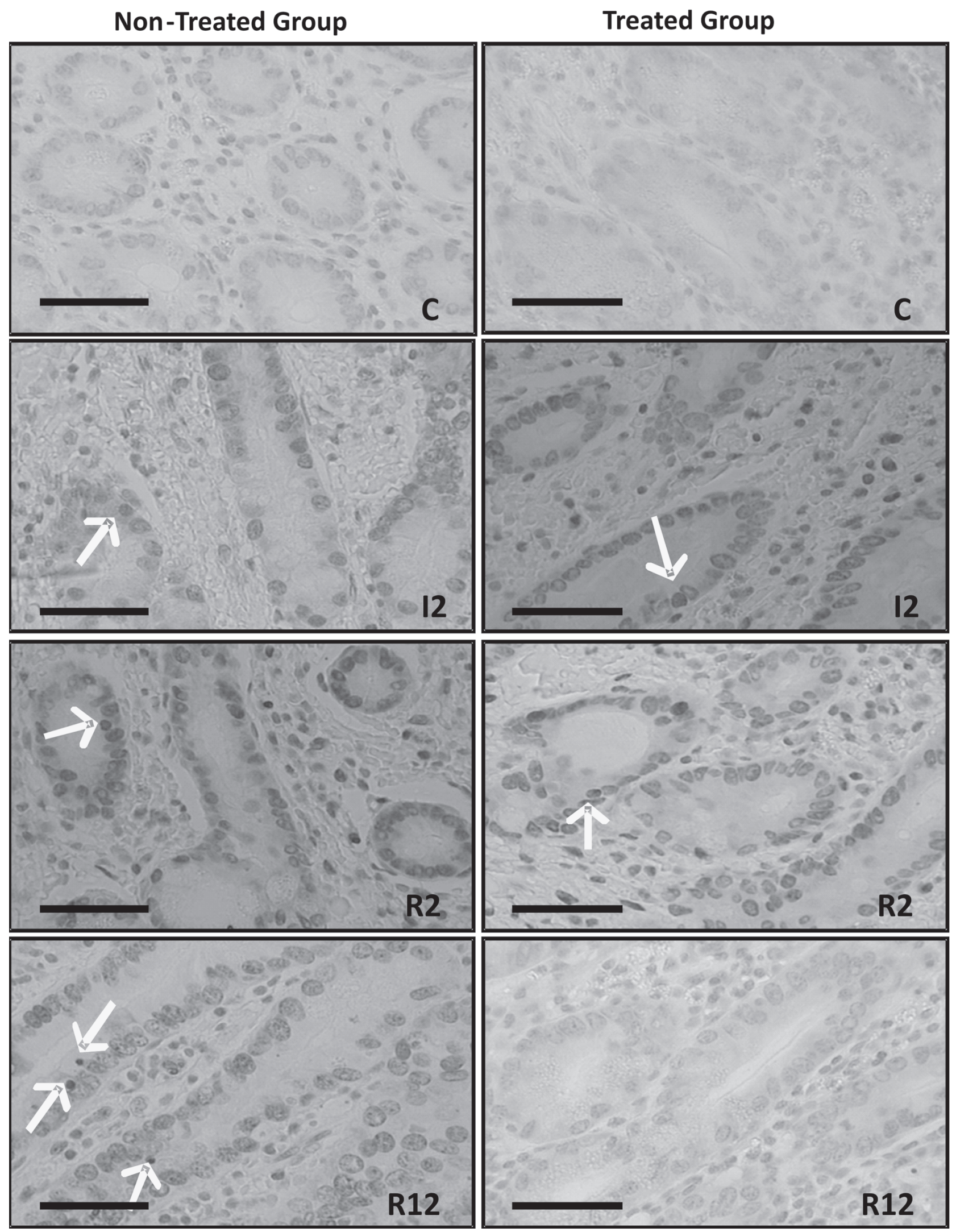

Fig.3. TUNEL stained jejunum of horses subjected to experimental ischemia and reperfusion. Non-Treated Group and Treated Group respectively: C (Control), $\mathbf{1 2}$ ( $2 \mathrm{~h}$ of the ischemia), $\mathbf{R} \mathbf{2}$ ( $2 \mathrm{~h}$ of the ischemia followed by $2 \mathrm{~h}$ of the reperfusion), $\mathbf{R} 12$ ( $2 \mathrm{~h}$ ischemia followed by $12 \mathrm{~h}$ of the reperfusion). Arrows indicate apoptotic epithelial cells. Bar: $200 \mathrm{~mm}$. 
cells were detached from the tips of the villi, leaving an exposed laminae propria (Fig.1). These pathological changes prevented an characterization of the villi, and the attainment of correspondent histological images. Therefore, it was not possible to quantitatively evaluate apoptosis in the villi.

In contrast to what was observed in the villi, there was almost no tissue disorganization in the crypts allowing the observation of its typical structure and identification of epithelial cells and the laminae propria.

As detailed in Figure 2 and Figure 3, differences in the apoptotic index among time points throughout the time course were not statistically significant $(P=0.056)$ in the untreated group. Importantly, the number of apoptotic cells per field was lower in the treated group at the end of the experimental period at $12 \mathrm{~h}$ of reperfusion $(P=0.012)$, indicating a beneficial effect of treatment.

\section{DISCUSSION AND CONCLUSION}

These results demonstrated that hydrocortisone partially prevents apoptosis in the jejunum of horses with I/R injuries. Interestingly, the effect of glucocorticoids (GC) on apoptosis varies according to the cell type (Amsterdam et al. 2002). GC inhibits apoptosis in hepatoma cells of murines, hepatocytes, neuthrophils, mouse fibroblasts and mouse gland mammary (Evans-Storms et al. 2000), whereas in immature thymocytes and other lymphoid cells it induces apoptosis (Messmer et al. 1999, Evans-Storms et al. 2000). In addition, GC can interfere with apoptosis by modulating expression of proteins belonging to the $\mathrm{Bcl}-2$ family. GC may inhibit expression of pro-apoptotic proteins such as Bcl-xs and it may activate expression of anti-apoptotic proteins such as $\mathrm{Bcl}-\mathrm{xL}$ and $\mathrm{Bcl}-2$. Finally, the action of GC on apoptosis depends on the balance between pro and anti-apoptotic factors that are activated (Amsterdam et al. 2002).

The effect of hydrocortisone observed in this study may also be due to inhibition of TNF $\alpha$, which has been implicated in the pathogenesis of ischemia/reperfusion injury (Esposito et al. 2007). Study demonstrated that the treatment with hydrocortisone reduced TNF $\alpha$ levels in the blood and in peritoneal fluid of horses subjected to experimental distension of the small colon (Faleiros et al. 2006). TNF $\alpha$ is an important mediator of $\mathrm{I} / \mathrm{R}$ injury. In rats, it was demonstrated that this injury causes increased levels of TNF $\alpha$ in the intestine. TNF $\alpha$ correlates positively with tissue damage, reduction of the survival rate in vivo, and modulates apoptosis. Thus, an anti-TNF $\alpha$ therapy is considered as an alternative treatment for $\mathrm{I} / \mathrm{R}$ injuries (Esposito et al. 2007). Furthermore, hydrocortisone inhibits TNF $\alpha$ induced apoptosis in glomerular endotelial cells (Messmer et al. 1999), and it is considered one of the most powerful inducers of apoptosis (Messmer et al. 1999). TNF $\alpha$ is the most potent ligand that triggers the extrinsic via of the apoptosis, and it acts concomitantly with TGF- $\beta$ regulating cell death in the intestine of neonatal pigs (Godlewski et al. 2007). Induction of apoptosis by TNF $\alpha$ involves a series of events that result in activation of caspase 3 (Messmer et al. 1999, Martin \& Wallace 2006), migration of cytochrome
$\mathrm{C}$ to the cytosol, increase of pro-apoptotic proteins such as Bak, and reduction of anti-apoptotic proteins such as Bcl-xL (Messmer et al. 1999). In bovine luteal cells culture, hydrocortisone suppressed the apoptosis induced by TNFalpha due to reduction of activity of caspase-3 and caspase-8 (Komiyama et al. 2008). These reports support the notion that hydrocortisone reduces apoptosis at 12 hours of reperfusion by inhibiting TNF $\alpha$. In addition to the effect of TNF $\alpha$ itself, it is interesting to consider also the role of its receptors: p75 is usually involved in generate necrosis and amplifying the inflammatory reaction, whereas p55 has a important anti-inflammatory effect as an inductor of apoptosis, modulating inflammation during the resolution phase.

In good agreement with the results of this study, Alves (2003) have demonstrated that hydrocortisone attenuates $\mathrm{I} / \mathrm{R}$ injuries at $2 \mathrm{~h}$ of reperfusion, favoring tissue repair at $12 \mathrm{~h}$ of reperfusion.

In this study, there was more structural damage in the villi compared with the crypts. This finding is in accordance with the findings of Esposito et al. (2007) and the citations of Mammen \& Matthews (2003). In rats subjected to intestinal $I / R$, there was severe tissue destruction of the villi, which was associated with inflammation and hemorrhage in the mucosa, whereas crypts were still preserved (Esposito et al. 2007). The villi are more vulnerable to injuries, including the ischemic insult. As an explanation to this difference, the epithelial turnover implies that apoptosis is more intense at the villi where older and apoptotic cells desquamate, while mitosis is more intense in crypts. When submitted to an oxidative stress, apoptosis will increase even more and will be more intense in villi than in crypts. Also the secretions proceeding from crypts and the rich vascularization of the submucosa may contribute for the fast dilution and removal of the toxic substance in this region (Mammen \& Matthews 2003). In conclusion, hydrocortisone inhibits I/R injury-induced apoptosis in equine jejunum, which is likely to contribute for attenuation of tissue damage.

Acknowledgements.- To CNPq and FAPEMIG for the financial support. GESA, ACV, RRF and RLS are CNPq research fellows.

\section{REFERENCES}

Alves G.E.S., Matos J.J.R.T., Faleiros R.R., Santos R.L. \& Marques Júnior A.P. 2003. Effect of hydrocortisone on reperfusion injury and on mucosal repair after experimental venous ischemia in the equine jejunum. Arq. Bras. Med. Vet. Zootec. 55:539-549.

Amsterdam A., Tajima K. \& Sasson R. 2002. Cell-specific regulation of apoptosis by glucocorticoids: Implication to their anti-inflammatory action. Biochem. Pharmacol. 64:843-850.

Cerqueira N.F., Hussni C.A. \& Yoshida W.B. 2005. Pathophysiology of mesenteric ischemia/reperfusion: A review. Acta Bras. Cir. 20:336-342.

Chae H.J., Chae S.W., Kang J.S., Bang B.G., Cho S.B., Park R.K., SO H.S., Kim Y.K., Kim H.M. \& Kim H.R. 2000. Dexamethasone Supresses Tumor Necrosis Factor- $\alpha$-Induced Apoptosis in Osteoblasts: Possible Role for Ceramide. Endrocrinology 141:2904-2913.

Esposito E., Mazzon E., Muià C., Meli R., Sessa E. \& Cuzzocrea S. 2007. Splanchnic ischemia and reperfusion injury is reduced by genetic or pharmacological inhibition of TNF- $\alpha$. J. Leukoc. Biol. 81:1-11. 
Evans-Storms R.B. \& Cidlowski J.A. 2000. Delineation of an Antiapoptotic Action of Glucocorticoids in Hepatoma Cells: The role of Nuclear Factor-KB. Endocrinology 141:1854-1862.

Faleiros R.R., Alves G.E.S., Santos R.L., Marques Júnior A.P. \& Macoris D.G. 2001. Experimental ischemia and reperfusion in equine small colon. Arq. Bras. Med. Vet. Zootec. 53:341-350.

Faleiros R.R., Macoris D.G. \& Massoco C.O. 2006. Hidrocortisona atenua resposta inflamatória promovida por distensão do cólon menor. Arq. Bras. Med. Vet. Zootec. 58(Supl.2):91.

Godlewski M.M., Hallay N., Bierla J.B. \& Zabielski L. 2007. Molecular mechanism of programmed cell death in the gut epithelium of neonatal piglets. J. Physiol. Pharmacol. 58(Suppl.3):97-113.

Houssain M.A., Park J., Choi S.H. \& Kim G. 2008. Dexamethasone induces apoptosis in proliferative canine tendon cells and chondrocytes. Vet. Comp. Orthop. Traumatol. 21:337-342.

Ikeda H., Suzuki Y., Suzuki M., Koike M., Tamura J., Tong J., Nomura M. \& Itoh G. 1998. Apoptosis is a major mode of cell death caused by ischaemia and ischaemia/reperfusion injury to the rat intestinal epithelium. Gut 42:530-537.

Kerr J.F.R., Wyllie A.H. \& Currie A.R. 1972. Apoptosis: A basic biological phenomenon with wide-ranging implications in tissue kinetics. Brit. J. Cancer 26:239-257.

Komiyama J., Nishimura R., Lee H., Sakumoto R., Tetsuka M., Acosta T.J., Skarzynski D.J. \& Okuda K. 2008. Cortisol is a suppressor of apoptosis in bovine corpus luteum. Biol. Reprod. 78:888-895.

Mammen J.M.V. \& Matthews J.B. 2003. Mucosal repair in the gastrointestinal tract. Crit. Care Med. 31(Suppl.8):S532-537.

Martin G.R. \& Wallace J.L. 2006. Gastrointestinal Inflammation: A central component of mucosal defense and repair. Exp. Biol. Med. 231:130137.

Mendes H.M.F., Faleiros R.R., Vasconcelos A.C., Alves G.E.S. \&
Moore R.M. 2009. Apoptosis in equine small colon subjected to experimental ischemia and reperfusion. Pesq. Vet. Bras. 29:198-204.

Messmer U.K., Winkel G., Briner V.A. \& Pfeilschifter J. 1999. Glucocorticoids potently block tumour necrosis factor- $\alpha$ - and lipopolysaccharide-induced apoptotic cell death in bovine glomerular endothelial cells upstream of caspase 3 activation. Brit. J. Pharmacol. 127:1633-1640.

Messmer U.K., Briner V.A. \& Pfeilschifter J. 1999. Tumour necrosis factor-alpha and lipopolysaccharide induce apoptotic cell death in bovine glomerular endothelial cells. Kidney Int. 55:2322-2337.

Moro L., Alves C.M., Santos F.G.A., Martins A.S. \& Vasconcelos A.C. 2004. Apoptose na desmielinização da cinomose canina (revisão de literatura). Biosci. J. 20:171-178.

Noda T., Iwakiri R., Fujimoto K., Matsuo S. \& Aw T.Y. 1998. Programmed cell death induced by ischemia-reperfusion in rat intestinal mucosa. Am. J. Physiol. Gastrointest. Liver Physiol. 274:270-276.

Pagliosa G.M., Alves G.E.S., Faleiros R.R., Rio Tinto J.J.M., Mendes H.M.F. \& Alves T. 2008. Associação de agentes terapêuticos no tratamento das obstruções intestinais e no desenvolvimento de lesões à distância em equinos. Anais VII Congresso Brasileiro de Cirurgia e Anestesiologia Veterinária, Recife. (CD-ROM)

Pagliosa G.M., Alves G.E.S., Faleiros R.R., Rio Tinto J.J.M., Torres M.B., Mendes H.M.F. \& Costa R.S. 2009. Use of glutamine to treatment of ischemia and reperfusion lesions in equine jejunum. Pesq. Vet. Bras. 29:246-252.

Parolin M.B. \& Reason I.J.M. 2001. Apoptose como mecanismo de lesão nas doenças hepatobiliares. Arq. Gastroenterol. 38: 138-144.

Takahashi T., Kadosawa T., Nagase M., Mochizuki M., Matsunaga S., Nishimura R. \& Sasaki N. 1997. Inhibitory effects of glucocorticoids on proliferation of canine mast cell tumor. J. Vet. Med. Sci. 59:9951001. 